\title{
Formulation, Efficacy and Immunogenicity Studies of a Liquid State Rabies Vaccine with Magnesium Chloride as Stabilizer
}

\author{
Selvaraj $\mathbf{J}^{1^{*}}$, Rajendran $\mathbf{V}^{{ }^{*}}$, Kuruba $\mathbf{B}^{3}$, Channappa $\mathbf{S K}^{1}$, Pachamuthu $\mathbf{R G}^{4}$ and Raju $\mathbf{M K}^{1}$ \\ ${ }^{1}$ Pasteur Institute of India, Coonoor, Tamilnadu, India \\ ${ }^{2}$ Department of Biochemistry, North Eastern Hill University, Shillong, Meghalaya, India \\ ${ }^{3}$ Cell and Molecular Biology Lab, Illinois Institute of Technology, Chicago \\ ${ }^{4}$ Department of Biotechnology, Jamal Mohammed College, Trichirapalli, Tamilnadu, India
}

*Corresponding author: Selvaraj J, Pasteur Institute of India, Coonoor, Pin-643103, Tamilnadu, India, Tel: +919894967811; +919089540954; E-mail: vijayakumar.thenilgiris@gmail.com, seljag2005@yahoo.com

Received date: Jul 04, 2015; Accepted date: Aug 25, 2015; Published date: Sep 02, 2015

Copyright: (C) 2015 Selvaraj J, et al. This is an open-access article distributed under the terms of the Creative Commons Attribution License, which permits unrestricted use, distribution, and reproduction in any medium, provided the original author and source are credited.

\begin{abstract}
Propagation of fixed rabies virus strain in vero cell line, ultra filtration of rabies viral harvest, betapropiolactone inactivation subsequent purification, total protein nitrogen quantification, Rapid Fluorescent focus inhibition test, $\mathrm{MgCl}_{2}$ based liquid rabies vaccine formulation (TCALRV-B) and immune response analysis. The vero cell derived PV 11 rabies viral titers were found that $10^{-5.3}$, ultra filtrated, betapropiolactone inactivated and viral protein qualities were within the range $(\mathrm{WHO})$. The total protein concentration and $\mathrm{PN}_{2}$ was $577.6,0.26 \mathrm{mg} / \mathrm{ml}$ respectively. The host cellular protein and residual cellular DNA was $16 \mathrm{ng} / \mathrm{single}$ human doses and below $100 \mathrm{pg} / \mathrm{ml}$ respectively it reveals within the limit. The RFFIT titer of the TCALRV-B possessed higher immune response $(8 \mathrm{IU} / \mathrm{ml})$ of rabies neutralizing antibodies on $14^{\text {th }}$ on $21^{\text {st }}$ day the titer was four fold increasing even after $90^{\text {th }}$ day it reveals its immunopotency. The TCALRV-B contained all the quality attributes to fulfill the regulatories although it contained potency, immunogenicity and safety as in vivo study shows lesser immunogenic during the booster doses. This may be due to the unadsorption of rabies viral proteins by $\mathrm{MgCl}_{2}$ as adjuvant.
\end{abstract}

\section{Key words:}

Rabies vaccine; Tissue culture; Human albumin; Magnesium chloride; RFFIT; SRID

\section{Introduction}

Rabies is one of the neglected tropical diseases caused by the lyssavirus, causing severe encephalomyelitis throughout the world. It thought to be one of the oldest diseases of mankind. In Asia, rabies is one of the most important diseases because high human mortality rate and high costs spend for prevention and treatment, A survey has shown that Asia carries a larger part of the public health burden of with an estimated 32,000 deaths [1], and 20,000 of human deaths in India every year [2]. India has approximately 25 million dogs, with a dog: man ratio was 1:36. 1.1 to 1.5 million persons gets post-exposure rabies vaccine annually in India and hence the annual requirement for rabies vaccine is approximately 6-10 million doses. The post exposure prophylaxis of rabies disease requires 4-5 doses of highly expensive cell culture derived vaccines for the entire period of immunization, in which case the poor people are unable to bear the cost. The high cost of cell culture rabies vaccine is due to the increased cost of production. Most of the available cell culture vaccines are in freeze dried form whereas processing of the rabies vaccine the maximum cost is needed for downstream purification and lyophilization process [3].

The currently available cell culture rabies viral vaccines were formulated with human albumin and maltose as a freeze dried state, various stabilizers are added during the preparation, in case of freeze dried vaccines it is mandatory, the immunogen presence was weak amount. If sufficient amounts of various preservative materials were not added while lyophilization, the vaccine would not be readily observable and undoubtedly adhere to the wall of the vaccine vial. But during the freeze drying process there is a losses of considerable antigenicity (immunogenic and potency) in the presence of human serum albumin the binding strength of rabies viral protein [4].

The Lyophilization process is a multistage operation in which, each step is utmost importance and critical, this process has to be adapted to individual vaccines according to the specific requirements, lowtemperature behavior of the different products. The formulated and filled vaccine materials are hardened while freezing process due to low temperatures, during this period; all fluids present become solid bodies, either crystalline, amorphous, or glass. Keeping this view in this study to do the liquid formulation of vero cell derived rabies vaccine with $\mathrm{MgCl}_{2}$ as a stabilizer as well as adjuvant.

\section{Materials and Methods}

\section{Vero cell propagation of rabies virus}

Vero cells (CCL-81) were obtained from the American Type Culture Collection (ATCC) at the passage number 125 as monolayer's frozen cells and propagated with appropriate medium [5]. Further it was revived, sub cultured and seeded into roller bottles $\left(2.5 \times 10^{-6}\right.$ cells $/ \mathrm{ml}$ ) [6] and the cultures were incubated at $37^{\circ} \mathrm{C}$ at $0.6 \mathrm{rpm}$. Fixed strain of Pasteur virus (PV-11) which was obtained from Institute Pasteur France was propagated and infected with vero cell line and the virus infectivity was analyzed $[5,6]$. The rabies infected vero cell supernatant (viral harvest) was collected and replenished with maintenance medium at every intervals of $72 \mathrm{hrs}$ for 4 harvests, it was 
tested their infectivity in mice (LD50) [7] and the viral titer was also calculated [8]. All the pertained chemicals are prepared with exact molar strength with distilled water, $30.49 \mathrm{~g}$ of magnesium chloride 6Hydrate HPLC grade (E Merck) was dissolved in $15 \mathrm{ml}$ of sterile distilled water before formulation all the reagents was checked its sterility test.

\section{Concentration, inactivation and purification of rabies virus}

Those viral harvests which have passed the in process quality control tests subsequently processed for concentration (CON), $\beta \mathrm{PL}$ inactivation (1:3000) [5,9], the $\beta \mathrm{PL}$ inactivated concentrate was tested for its quality [10]. Concentrated, inactivated rabies viral proteins were underwent purification for the removal of impurities like host cellular protein (HCP) and residual cellular DNA, the purified materials are analyzed the tests like total protein concentration, mouse infectivity titer, in vitro potency.

\section{Quality attributes of rabies viral proteins}

The purified, quality tested desalted rabies viral proteins were formulated with magnesium chloride and human serum albumin, Further it was subjected to their quality control tests like sterility test, $\mathrm{pH}$, abnormal toxicity, and innocuity [5].

The single human dose was used for immune response analysis, the total protein was measured using with Bicinconinic acid protein assay kit $[11,12]$, protein nitrogen content was analyzed by the sulphuric digestion (microkjeldhel) method [5]. The immune sera's of guinea pig were confirmed through RFFIT [13]. Local reference vaccine (zonal centrifuge purified) which calibrated against WHO standard vaccine, was used as standard.

\section{Liquid vaccine formulation}

All the components were prepared with analytical grade chemicals and deionized water was used for formulation. Human albumin $20 \%$ was obtained from Reliance life sciences, the purified rabies virus protein (PRVP) (total protein- $577.6 \mathrm{mg} / \mathrm{ml}$ ) and $1 \mathrm{M}$ magnesium chloride was taken. As per regulatory the purified rabies proteins, stabilizers, additives and adjuvants should be more than $2.5 \mathrm{IU}, 5 \%$, $1 \%$ and less than $2 \mathrm{mg} /$ single human dose respectively. Human albumin was added as additives to a final concentration of $1 \%$, the vaccine was formulated (Table 1), and it named as tissue culture anti liquid rabies vaccine-B (TCALRV-B). This formulation was carried out in the $+4^{\circ} \mathrm{C}$ to avoid protein loss as well as avoid protein clumps, after addition of all the formulators it was under mild shaking for proper mixing, and same time without froth formation the same was repeated up to 2 days.

\begin{tabular}{|l|l|l|l|l|l|}
\hline \multirow{2}{*}{} & \multicolumn{4}{|l|}{ Constituent present in Liquid rabies vaccine } \\
\cline { 2 - 6 } & $\begin{array}{l}\text { Purified rabies } \\
\text { viral proteins (\%) } \\
\text { Total protein } \\
\text { Vaccine }\end{array}$ & $\begin{array}{l}\text { Human } \\
\text { Serum } \\
\text { Albumin } \\
(\%)\end{array}$ & $\begin{array}{l}\text { MgCl } \\
(\mathbf{m l})\end{array}$ & $\begin{array}{l}\text { Total } \\
\text { protein } \\
\mu \text { g/dose }\end{array}$ & pH \\
\hline TCALRV-B & $54.70 \%$ & 1 & 20.3 & 65 & 7.2 \\
\hline
\end{tabular}

Table 1: Traits of liquid rabies vaccine at formulation.

\section{Analysis of seroconversion rate of rabies antibodies}

Group of 2 guinea pigs were immunized intraperitonially with two doses of $0.03 \mathrm{ml}$ of TCALRV-B and references vaccines (HO23 and TCARV) with pertained adjuvants. The animals are challenged intracerabrally with $20 \mathrm{LD}_{50} / 0.003 \mathrm{ml}$ of CVS, the immunogenicity of the vaccines was performed with pre exposure schemes $\left(D_{0}, D_{7}, D_{14}\right.$, and $\left.\mathrm{D}_{21}\right)$. Three milliliters of whole blood specimens were collected on day 0,14 and 45 after the first dose injection respectively. The serum samples were separated from the collected blood specimens and stored at $-20^{\circ} \mathrm{C}$ until using. Rabies virus neutralizing antibody levels were measured using the rapid fluorescent focus inhibition test (RFFIT), as recommended by the WHO [13].

Reaching adequate rabies virus neutralizing antibody (RVNA) concentrations of $0.5 \mathrm{IU} / \mathrm{ml}$ was defined as seroconversion based on the WHO criteria and considered to be positive [14].

\section{Results and Discussion}

\section{Preparation and quality control of TCALRV-B}

The PV 11 rabies viruses were harvested at 72 hours intervals until the $4^{\text {th }}$ day, and viral titers were determined and it found that $10^{-5.3}$ furthermore it was concentrated about 20 times using with $0.45 \mu \mathrm{m}$ microfiltration (clarification) and ultrafiltration $(100 \mathrm{KDa})$, then inactivated with $\beta$-propiolactone (1:3000) at $4^{\circ} \mathrm{C}$ [9]. After completion of quality tests, chromatographic purification was conducted and the quality attributes of the samples are within the limit as IP 2014 (Table 2).

\begin{tabular}{|c|c|c|c|c|c|c|c|c|c|}
\hline \multirow[b]{2}{*}{ Sample } & \multirow[b]{2}{*}{ Sterility } & \multirow[b]{2}{*}{ pH } & \multicolumn{2}{|c|}{ Protein purity } & \multirow[t]{2}{*}{$\begin{array}{l}\text { Total protein } \\
\text { (BCA) }(\mathrm{mg} / \mathrm{ml})\end{array}$} & \multirow{2}{*}{$\begin{array}{l}\mathrm{PN}_{2} \\
(\mathrm{mg} / \mathrm{ml})\end{array}$} & \multirow{2}{*}{$\begin{array}{l}\text { Host cellular } \\
\text { BSA }(\mathrm{ng} / \mathrm{ml})\end{array}$} & \multirow{2}{*}{$\begin{array}{l}\text { Residual DNA } \\
(\mathrm{ng} / \mathrm{ml})\end{array}$} & \multirow{2}{*}{ SRID } \\
\hline & & & $\mathbf{A}_{260} / \mathbf{A}_{280}$ & $\%$ Protein & & & & & \\
\hline PRVP & Passed & 7.02 & 1.562 & 82 & 577.6 & 0.26 & Below $16 \mathrm{ng}$ & Below $100 \mathrm{pg}$ & + \\
\hline
\end{tabular}

Table 2: Quality attributes of purified rabies viral protein before formulation

The total protein concentration of sample was $577.6 \mathrm{mg} / \mathrm{ml}$, and it reflects their viral protein concentrations. In case of $\mathrm{PN}_{2}$ content (microkjeldhel method), their results were found to be $0.26 \mathrm{mg} / \mathrm{ml}$, it showed higher amount protein as well the purity because most virulent part of the rabies virus as protein hence the protein contents play a main role in the part of potency determinant. The sample was further tested for host cellular BSA by immunoenzymetric assay kit, and the values are below $16 \mathrm{ng}$, it was lower than the level of $50 \mathrm{ng} / \mathrm{ml}$ [5]. For the impurities analysis the residual cellular DNA by slot blot hybridization [15]. And the result values are below $100 \mathrm{pg} / \mathrm{ml}$ this test values are within the regulatory stipulated norms i.e $10 \mathrm{ng} / \mathrm{ml}$ [5]. 
Citation: Selvaraj J, Rajendran V, Kuruba B, Channappa SK, Pachamuthu RG, et al. (2015) Formulation, Efficacy and Immunogenicity Studies of a Liquid State Rabies Vaccine with Magnesium Chloride as Stabilizer. J Vaccines Vaccin 6: 292. doi:10.4172/2157-7560.1000292

Page 3 of 4

The PRVP was formulated with $1 \mathrm{M} \mathrm{MgCl}_{2}$ (20.3\%) human serum albumin (1\%) the total protein concentration was kept as $65 \mu \mathrm{g} / \mathrm{dose}$, during the liquid formulation the $\mathrm{pH}$ of the vaccine was 7.2. The final concentration of $\mathrm{MgCl}_{2}$ was analyzed by titan yellow method $[4,16]$ and the concentration was $20.3 \mathrm{ml}$ (20\%). Magnesium chloride present in vaccine sample was estimated using titan yellow as a coloring agent, the concentration was as 0.083 in single human dose (SHD) [4].

Human serum albumin (HSA), the most abundant protein in plasma, is a major antioxidant, transport, and depot protein. This globular $66 \mathrm{KDa}$ protein contains 585 amino acids including 18 tyrosines, 6 methionines, 1 tryptophan, 17 disulfide bridges, and only 1 free cysteine (Cys34). Many commercial HSA preparations come as a sterile aqueous solution prepared by a cold alcohol fractionation method from pooled human plasma obtained from venous blood. The HSA products are available at $20 \%(20 \mathrm{~g} / 100 \mathrm{ml})$. It is used predominantly in the preparation of viral vaccines [17] and it is also used as vaccine additives [18].

Storing proteins in liquid state has numerous advantages, the process of thawing and rehydration decrease its stability of protein. Less manipulation is required for the formulation than for freeze dried form. Protein stability is directly correlated with the ability of water in the hydration layer to fluctuate among different equilibrium structure [19]. Viral vaccines are highly sensitive, respond differently to physical stresses, commonly it can be affected differently by solvents, $\mathrm{pH}$, and ionic strength of extreme temperatures (heat/cold) [20].

As per the regulatory requirements the TCALRV-B was passed its safety, efficacy and potency tests (Table 3), the abnormal toxicity test is the general requirement for all vaccines, the mice and guinea pigs were inoculated with TCALRV-B, reference vaccines through intraperitonially, all the animals are observed for 7 days, during that period there was no death, necrosis and weight loss it revealed absence of abnormal toxicity.

\begin{tabular}{|l|l|l|}
\hline Quality Tests & $\begin{array}{l}\text { IP 2014 of rabies } \\
\text { vaccine }\end{array}$ & TCALRV-B \\
\hline Sterility test & Negative (-) & Negative (-) \\
\hline $\begin{array}{l}\text { Residual } \\
\text { Albumin }\end{array}$ & $\leq 50 \mathrm{ng} /$ dose & $16 \mathrm{ng} / \mathrm{dose}$ \\
\hline Residual BPL & Not more than 1:3500 & Below the level \\
\hline Potency & $\geq 2.5$ IU/dose & $\geq 3.1$ IU/dose \\
\hline $\begin{array}{l}\text { Residual Vero cell } \\
\text { DNA }\end{array}$ & $\leq 100 \mathrm{pg} / \mathrm{dose}$ & $10 \mathrm{pg} / \mathrm{dose}$ \\
\hline Bacterial Endotoxin & $\leq 50 \mathrm{EU} /$ dose & $\leq 50 \mathrm{EU} / \mathrm{dose}$ \\
\hline Protein content & $\leq 80 \mu \mathrm{g} / \mathrm{dose}$ & $65 \mu \mathrm{g} / \mathrm{dose}$ \\
\hline pH & $7.2-8.0$ & 7.8 \\
\hline Abnormal Toxicity & Passed & Passed \\
\hline Avirulence Test & Negative & Negative \\
\hline $\begin{array}{l}\text { Virus } \\
\text { Test }\end{array}$ & Negative & \\
\hline
\end{tabular}

Table 3: Quality attributes of TCALRV-B

\section{Seroconversion of TCALRV-B}

The in vitro potency of the TCALRV-B was analyzed through RFFIT method, due to avoiding the usage of more animals, the potency of inactivated rabies vaccines is conventionally determined by a mouse challenge test, and this method causes severe distress to the test animals and is known to be imprecise and time-consuming. So WHO and many countries drug agency suggest the method of rapid and reproducible in vitro the availability of alternatives, this method remains the standard method for measuring rabies-specific antibodies [21]. The RFFIT method spend only 2 days, and can detect a large number of samples once time, and do not require the use of animals (3R principles of experimental animals), WHO strongly recommended the method, RFFIT method has been the approved by the agency of drug regulatory of China for the potency detection of anti-rabies serum/immunoglobulin now [22].

The RFFIT results of the TCALRV-B was in the Table 4, and found to be the rabies neutralizing antibodies value of TCALRV-B, HO23 and reference freeze dried vaccine (control vaccines) on the $7^{\text {th }}$ day it was $<05$ and it shows all the animals are not in the required values [18].In case of $14^{\text {th }}, 21^{\text {st }}$ and $90^{\text {th }}$ day the values are increased and it reached above $2.5 \mathrm{IU} / \mathrm{ml}$ it reveals higher immunogenicity, in case of the TCALRV-B it also possessed higher immune response. The TCALRV-B immunized guinea pigs blood sera's was showed $8 \mathrm{IU} / \mathrm{ml}$ (RFFIT) of rabies neutralizing antibodies on $14^{\text {th }}$ day. The antibodies level rate was increased four folds after $21^{\text {st }}$ day and continued the same increase rate even after $90^{\text {th }}$ day it reveals its immunopotency.

\begin{tabular}{|c|c|c|c|c|c|c|}
\hline \multirow{3}{*}{ Vaccine } & \multirow{3}{*}{$\begin{array}{l}\text { No. of } \\
\text { animals } \\
\text { used }\end{array}$} & \multicolumn{5}{|l|}{ RFFIT } \\
\hline & & \multicolumn{5}{|c|}{ Rabies Neutralizing antibodies in IU/mI } \\
\hline & & $0^{\text {th }}$ day & $7^{\text {th }}$ day & $14^{\text {th }}$ day & $21^{\text {st }}$ day & $\begin{array}{l}90^{\text {th }} \\
\text { day }\end{array}$ \\
\hline $\begin{array}{l}\text { TCALRV - } \\
\mathrm{B}\end{array}$ & 8 & $<05$ & $<05$ & 8 & $>32$ & $32-64$ \\
\hline $\begin{array}{l}\text { Local } \\
\text { reference }\end{array}$ & \multirow[t]{2}{*}{8} & \multirow[t]{2}{*}{$<05$} & \multirow[t]{2}{*}{$<05$} & \multirow[t]{2}{*}{$16-32$} & \multirow[t]{2}{*}{64} & \multirow[t]{2}{*}{64} \\
\hline$(\mathrm{HO} 23)$ & & & & & & \\
\hline $\begin{array}{l}\text { Reference } \\
\text { Freeze }\end{array}$ & \multirow{2}{*}{8} & \multirow{2}{*}{$<05$} & \multirow{2}{*}{$<05$} & \multirow{2}{*}{16} & \multirow{2}{*}{$32-64$} & \multirow{2}{*}{64} \\
\hline $\begin{array}{l}\text { dried } \\
\text { vaccine }\end{array}$ & & & & & & \\
\hline Dose $1 \mathrm{ml}, \mathrm{l}$ & on days & th & for bot & & & \\
\hline
\end{tabular}

Table 4: Immunogenicity of TCALRV-B

Magnesium chloride is used as the stabilizer as well as adjuvants in oral polio vaccine for human use [23]. The magnesium chloride is boosting the immune response when combined with polio vaccine [24]. Additives are used to stabilize the vaccines from adverse conditions such as freeze drying and heat. In addition, additives are added to vaccines to avoid immunogens from adhering to the side of the vial. There is no published data available with respect to use of different stabilizers in the preparation of rabies vaccine as liquid state. 
Citation: Selvaraj J, Rajendran V, Kuruba B, Channappa SK, Pachamuthu RG, et al. (2015) Formulation, Efficacy and Immunogenicity Studies of a Liquid State Rabies Vaccine with Magnesium Chloride as Stabilizer. J Vaccines Vaccin 6: 292. doi:10.4172/2157-7560.1000292

Page 4 of 4

\section{Conclusion}

Wenqiang Jiao et al. [25] stated in that new kind of adjuvants which could be used to enhance the potency of the vaccine, it needs to be developed. Also immunization strategies could also be developed. Immunologic adjuvants are agents incorporated into vaccine formulation to enhance the immunogenicity of vaccine antigens. The immunogenicity of a vaccine is defined as its ability to evoke an immune response in the vaccinated individual [17]. Although the formulated vaccine contained its potency, immunogenicity and safety in in vitro studies as $\mathrm{MgCl}_{2}$ as stabilizer, the in vivo study shows lesser immunogenic during the booster doses. This may be due to the unadsorption of rabies viral proteins by $\mathrm{MgCl}_{2}$ as adjuvant. This research study reveals to need a further study to focus on the adjuvancity of magnesium chloride.

\section{Acknowledgement}

The authors sincerely thanks to the Director, PII, Coonoor for providing facility to carry out this study, and also, the technical help and supports received from all technical staffs especially Mr.D.Surenderan of Department of Tissue culture anti rabies vaccine, Pasteur Institute of India Coonoor, Tamilnadu, India is highly acknowledged.

\section{References}

1. M Sugiyama, Naoto Ito (2007) Control of rabies: Epidemiology of rabies in Asia and development of new-generation vaccines for rabies. Comparative Immunology, Microbiology and Infectious Diseases 30: 273-286.

2. T Burki (2008) The global fight against rabies. The Lancet 372: 1135-1136.

3. Jagannathan S, Vijayakumar R, RahulGandhi P, Ananthi M, Chandra Charles, et al. (2010) Analysis of Carbohydrates in Newly Developed Liquid State Rabies Vaccine. Journal of Microbial and Biochemical Technology 2: 147-151.

4. Jagannathan S, Mani KR, Vijayakumar R, Rahul Gandhi P, Venkataramana KN (2011) Comparative analysis of magnesium chloride in recently developed liquid state rabies vaccine. International Journal of Pharma \& Bio Sciences 2: 473-479.

5. IPC (2010) Indian Pharmacopoeia. Indian Pharmacopoeia Commission (6edn).

6. S Jagannathan, S Chaansha, K Rajesh, T Santhiya, C Charles, KN Venkataramana (2009) Standardization and assessment of cell culture media quantities in roller poly ethylene terephthalate bottles employed in the industrial rabies viral vaccine production. Pakistan journal of biological sciences 12: 1246-1252.

7. Atanasiu P (1972) Quantitative assay and potency test of antirabies serum and immunoglobulin. Monograph series. World Health Organization pp: 314-318.
8. Reed LJ, Muench H (1938) A simple method of estimating fifty percent endpoints. American Journal of Epidemiology 27: 493-497.

9. S Jagannathan, P Rahul Gandhi, R Vijayakumar (2013) Kinetics Analysis of Beta-propiolactone with Tangential Flow Filtration (TFF) Concentrated Vero Cell Derived Rabies Viral Protein. Journal of Biological Sciences 13: 521-527.

10. Seligmann EB Jr (1973) Laboratory techniques in rabies: the NIH test for potency. Monogr Ser World Health Organ 23: 279-86.

11. Smith PK, Krohn RI, Hermanson GT, Mallia AK, Gartner FH, et al. (1985) Measurement of protein using bicinchoninic acid. Anal Biochem 150: 76-85.

12. S Jagannathan, KR Mani, R Vijayakumar (2015) Analysis of alternative purification of beta-propiolactone inactivated, Tangential Flow Filtration concentrated Vero cell derived rabies vaccine. Journal of Vaccines and Vaccination 6: 1-6.

13. MR Green, J Sambrook (2000) Molecular cloning: a laboratory manual ( $3^{\text {rd }}$ edn.) Cold Spring Harbor Laboratory Press, New York.

14. Mirchamsy H, Shafyi A, Mahinpour M, Nazari P (1978) Stabilizing effect of magnesium chloride and sucrose on Sabin live polio vacine. Dev Biol Stand 41: 255-257.

15. JS Smith, PA Yager, GM Baer (1973) A rapid reproducible test for determining rabies neutralizing antibody. Bulletin of the World Health Organization 48: 535-541.

16. World Health Organization (2004) WHO expert consultation on Rabies: first Report. In: WHO Technical Report Series 931, pp. 1-121.

17. Plotkin SA (2010) Correlates of protection induced by vaccination. Clin Vaccine Immunol 17: 1055-1065.

18. World Health Organization (1994) WHO Expert committee on biological standardization- Annexure 4. In: WHO Technical Report Series No 840. Newyork, pp. 202-204.

19. Scharnagl C, Reif M, Friedrich J (2005) Stability of proteins: Temperature, pressure and the role of the solvent. Biochimica et Biophysica Acta (BBA) - Proteins and Proteomics 1749: 187-213.

20. Abdul-Fattah A, Truong-Le V, Yee L, Pan E, Ao Y, et al. (2007) DryingInduced Variations in Physico-Chemical Properties of Amorphous Pharmaceuticals and Their Impact on Stability II: Stability of a Vaccine. Pharmaceutical Research 24: 715-727.

21. Moore SM, Hanlon CA (2010) Rabies-specific antibodies: measuring surrogates of protection against a fatal disease. PLoS neglected tropical diseases 4: e595.

22. Cao S, Li J, Shi L, Wang Y, Wang X, et al. (2012) Replacement Study on the Potency Test of Anti-rabies Immunoglobulin in China. Journal of Applied Virology 1:27-33.

23. World Health Organization (1973): WHO expert committee on biological standardization. In: World Health Organization Technical Report Series No 530. Newyork, pp. 1-66.

24. Sokhey J, Gupta CK, Sharma B, Singh H (1988) Stability of oral polio vaccine at different temperatures. Vaccine 6: 12-13.

25. Jiao W, Yin X, Li X, Liu J (2012) Research Advancement in RV Novel Vaccine. Asian Journal of Animal \& Veterinary Advances 7: 1234-1244 